\title{
Molecular Evidence of Drug-Resistant Tuberculosis in the Balimo Region of Papua New Guinea
}

\author{
Tanya Diefenbach-Elstob ${ }^{1,2, *, \ddagger}$, Vanina Guernier ${ }^{2, t, \ddagger}$, Graham Burgess ${ }^{1} \mathbb{D}$, Daniel Pelowa ${ }^{3}$, \\ Robert Dowi ${ }^{3}$, Bisato Gula ${ }^{3}$, Munish Puri ${ }^{1}$, William Pomat ${ }^{4}$, Emma McBryde ${ }^{2}$, \\ David Plummer ${ }^{1}$, Catherine Rush ${ }^{1,2}$ and Jeffrey Warner ${ }^{1,2}$ \\ 1 College of Public Health, Medical and Veterinary Sciences, James Cook University, Townsville 4811, \\ Australia; graham.burgess@jcu.edu.au (G.B.); munish.puri@my.jcu.edu.au (M.P.); \\ david.plummer@jcu.edu.au (D.P.); catherine.rush@jcu.edu.au (C.R.); jeffrey.warner@jcu.edu.au (J.W.) \\ 2 Australian Institute of Tropical Health and Medicine, James Cook University, Townsville 4811, Australia; \\ vanina.guernier@gmail.com (V.G.); emma.mcbryde@jcu.edu.au (E.M.) \\ 3 Balimo District Hospital, Balimo 336, Papua New Guinea; tanya.elstob@jcu.edu.au (D.P.); \\ dowir733@gmail.com (R.D.); bisatokela01@gmail.com (B.G.) \\ 4 Papua New Guinea Institute of Medical Research, Goroka 441, Papua New Guinea; \\ william.pomat@pngimr.org.pg \\ * Correspondence: tanya.elstob@my.jcu.edu.au or tanya.diefenbachelstob@gmail.com \\ + Current address: Geelong Centre for Emerging Infectious Diseases, Deakin University, School of Medicine, \\ Geelong 3220, Australia \\ $\ddagger$ These authors contributed equally to this work.
}

Received: 29 January 2019; Accepted: 8 February 2019; Published: 10 February 2019

\begin{abstract}
Papua New Guinea (PNG) has a high burden of tuberculosis (TB), including drug-resistant TB (DR-TB). DR-TB has been identified in patients in Western Province, although there has been limited study outside the provincial capital of Daru. This study focuses on the Balimo region of Western Province, aiming to identify the proportion of DR-TB, and characterise Mycobacterium tuberculosis (MTB) drug resistance-associated gene mutations. Sputum samples were investigated for MTB infection using published molecular methods. DNA from MTB-positive samples was amplified and sequenced, targeting the $r p o B$ and $k a t G$ genes to identify mutations associated with rifampicin and isoniazid resistance respectively. A total of 240 sputum samples were collected at Balimo District Hospital (BDH). Of these, 86 were classified as positive based on the results of the molecular assays. For samples where $r p o B$ sequencing was successful, 10.0\% (5/50, 95\% CI 4.4-21.4\%) were considered rifampicin-resistant through detection of drug resistance-associated mutations. We have identified high rates of presumptive DR-TB in the Balimo region of Western Province, PNG. These results emphasise the importance of further surveillance, and strengthening of diagnostic and treatment services at BDH and throughout Western Province, to facilitate detection and treatment of DR-TB, and limit transmission in this setting.
\end{abstract}

Keywords: tuberculosis; Mycobacterium tuberculosis; drug resistance; real-time PCR

\section{Introduction}

Papua New Guinea (PNG) is considered to have a high burden of tuberculosis (TB) and drug-resistant TB (DR-TB) [1]. In 2017, the estimated incidence of TB was 432 cases per 100,000 people nationally, while in 2016 the case notification rate for Western Province was 674 per 100,000 people [1,2]. Despite the high burden of TB, HIV is not considered to be a main driver of TB in Western Province [3]. In 2017, the national proportion of DR-TB was $3.4 \%$ of newly diagnosed TB cases, and $26 \%$ of 
previously treated cases, with this proportion including both rifampicin (RIF)-resistant TB (RR-TB) and multidrug-resistant TB (MDR-TB) (resistance to both RIF and isoniazid (INH)) [1].

Studies undertaken in PNG have identified MDR-TB at sites in Eastern Highlands, Gulf, Madang, Milne Bay, Morobe, and Western provinces, and the National Capital District [4-8]. At Daru Hospital in the provincial capital of Western Province, MDR-TB has been reported in 34.2\% of new and previously treated cases, and extensively drug-resistant TB (MDR-TB with additional fluoroquinolone and second-line injectable antibiotic resistance) has also been described [3,4,9-13]. Other studies have found MDR-TB in $25 \%$ of Western Province-based TB patients presenting at Australian health clinics in the Torres Strait $[14,15]$. However, no previous research has investigated DR-TB in the Middle Fly District of Western Province, and the geographic origin of DR-TB patient samples referred to Daru Hospital (the referral hospital for DR-TB in the province) has not been reported.

Phenotypic drug susceptibility testing (DST) of Mycobacterium tuberculosis (MTB) bacilli isolated and cultured from patient clinical samples serves as a reference standard for the diagnosis of DR-TB [16]. However, culture-independent molecular methods have advantages over DST due to rapid turnaround time, and the ability to be used outside high-containment laboratories.

The molecular basis of RIF resistance has been well-characterised, with $96 \%$ of this resistance associated with mutations in an 81-base-pair (bp) hypervariable RIF-resistance determining region (RRDR) in the $r p o B$ gene $[17,18]$. In addition, resistance to INH has been associated with mutations in the kat $G$ and inh $A$ genes $[17,19]$. Because a large proportion of RIF-resistant strains have concomitant INH resistance, molecular detection of RIF resistance is often used as an early indicator of MDR-TB before phenotypic susceptibilities are available, or in countries where DST is not routinely available [20]. However, the pattern and frequency of mutations in the rpoB and $k a t G$ genes in MTB clinical isolates have significant geographic variability [21,22]. As a result, techniques that focus only on rpoB, such as the World Health Organization (WHO)-recommended Xpert MTB/RIF (Cepheid, USA), may overestimate MDR-TB, especially if the local prevalence of RR-TB is unknown. Therefore, an approach that can identify both rpoB and kat $G$ mutations is more likely to differentiate RR-TB, MDR-TB, and strains in which MDR-TB is likely to develop (pre-MDR-TB) [23].

The Balimo region in the Middle Fly District of Western Province is known to have a high burden of TB [24], with limited diagnostic facilities and smear microscopy being the only laboratory-based method of TB diagnosis available at Balimo District Hospital (BDH). Given the TB epidemic in Western Province, combined with limited data from areas outside the provincial capital, the aim of this study was to characterise the extent and type of molecular DR-TB in the remote Balimo region. As a preliminary study into DR-TB in this region, where techniques such as the Xpert MTB/RIF are not available, we used a pragmatic approach focused on the characterisation of RIF and INH resistance, based on mutations in the $r p o B$ and $k a t G$ genes. We characterised molecular evidence of resistance using DNA extracted directly from sputum samples collected at BDH. This study furthers understanding of the burden of DR-TB in Western Province.

\section{Study Population and Methods}

\subsection{Study Setting}

Balimo is a town of approximately 4400 people and is the urban centre of the Gogodala Rural local level government area in the Middle Fly District of Western Province [25]. Numerous small villages make up the Gogodala region, with a population of approximately 33,000 people [25]. The region is geographically remote with limited road networks, and travel is primarily by boat or by foot. Income is limited, with most people having subsistence-based livelihoods.

The primary health facility serving the region is BDH. However, the hospital has been without a physician for many years, and staffed by health extension officers and nurses. At the hospital, diagnosis of TB relies on clinical presentation and smear microscopy results, and is based on the PNG National Tuberculosis Management Protocol $[24,26,27]$. The hospital laboratory does not have the 
capacity for culture or Xpert MTB/RIF-based diagnosis of TB. Patients can be commenced on treatment for drug-susceptible TB, while presumptive DR-TB cases must be referred to Daru Hospital. For this study, sputum samples were collected from presumptive TB patients as part of routine passive case detection activities at $\mathrm{BDH}$. Associated demographic and clinical data were obtained from the BDH laboratory register, however information about the TB treatment history of patients was not available from this register.

\subsection{Initial Collection and Preparation of Samples}

Sputum samples were collected during the period from April 2016 to June 2017, as part of ongoing passive case detection of TB as per the BDH clinical procedures. A total of 240 samples were provided on a convenience sampling basis for this study. Processed sputum $(n=213)$ was prepared at the BDH laboratory, using decontamination and concentration procedures according to the modified Petroff's method $[28,29]$, and stored at $-20^{\circ} \mathrm{C}$. Following processing, sputum was smeared onto microscope slides, and examined for the presence of acid-fast bacilli using Ziehl-Neelsen (ZN) staining. Fresh sputum samples $(n=27)$ were collected in the few days prior to transfer of the samples to Townsville. For this reason, the fresh sputum samples could not be processed at BDH as usual, and instead were decontaminated and concentrated at James Cook University, Townsville, following the same procedure used at $\mathrm{BDH}$.

\subsection{Preparation of DNA Template}

Approximately $100-150 \mu \mathrm{L}$ of each decontaminated sputum was transferred to a $2 \mathrm{~mL}$ tube and heat inactivated at $80^{\circ} \mathrm{C}$ in a thermal block for $1 \mathrm{~h}$. Sputum was then centrifuged at $3000 \times g$ for $15 \mathrm{~min}$, and supernatant removed. A volume of $1 \mathrm{~mL}$ of a $4 \mathrm{M}$ guanidine isothiocyanate (GIT) solution was added to each tube, and incubated overnight at $37^{\circ} \mathrm{C}$. Samples were then centrifuged at $13,000 \mathrm{rpm}$ for $10 \mathrm{~min}$, and supernatant removed.

Following inactivation, DNA was extracted using the High Pure PCR Template Preparation Kit (Roche Diagnostics, Germany). The spun pellets were resuspended in $200 \mu \mathrm{L}$ of tissue lysis buffer, and $40 \mu \mathrm{L}$ of proteinase $\mathrm{K}$ solution, and incubated overnight at $55^{\circ} \mathrm{C}$, or until all sediment was dissolved. Subsequent steps were performed according to the manufacturer's instructions. Extracted DNA was stored at $-80^{\circ} \mathrm{C}$ until use.

\subsection{Confirmation of MTBC Infection}

Two TaqMan real-time polymerase chain reaction (qPCR) assays were used to confirm the presence of the Mycobacterium species (IS6110 assay) or M. tuberculosis complex (MTBC) (senX3-regX3 assay) in the DNA extracts, according to published protocols [30]. While the senX3-regX3 intergenic region is specific to the MTBC, IS6110 is present in most strains of M. tuberculosis, but has also been identified in other species of Mycobacterium, including non-tuberculous mycobacteria (NTM). Both targets were used because the IS6110 assay, which targets a multicopy element, is more sensitive than the senX3-regX3 assay, which targets a single copy gene [30].

Each qPCR reaction $(20 \mu \mathrm{L})$ contained 1X GoTaq Probe qPCR Master Mix (Promega, Madison, WI, USA), $0.8 \mu \mathrm{M}$ each of forward and reverse primer, $0.1 \mu \mathrm{M}$ of probe, and $2 \mu \mathrm{L}$ of DNA template. The positive control used MTB H37Rv (GenBank: AL123456.3). Cycling parameters are shown in Table 1. qPCR assays were carried out on a Rotor-Gene Q6000 (QIAGEN, Hilden, Germany).

Each sample was assayed in duplicate for the IS6110 qPCR, with a triplicate assay for discordant results, and assayed once for the senX3-regX3 qPCR. A sample was considered reactive if the cycle threshold (Cq) was less than 40 cycles. Samples with duplicate reactivity of the IS6110 assay as well as reactivity of the senX3-regX3 assay were considered MTB-positive, while samples with duplicate reactivity of the IS6110 assay only were classified as MTBC/NTM. In PNG, only a small number of NTM strains have been identified, and they are likely to have limited influence in the context of our 
study $[4,26,31]$. However, because the possibility of rare NTM in the IS6110-positive samples cannot be completely excluded, we have used the 'MTBC/NTM' classification for accuracy.

Table 1. Cycling parameters for the real-time PCR ( $\mathrm{qPCR}$ ) and conventional PCR ( $r p o B$ and $k a t G$ ) assays.

\begin{tabular}{|c|c|c|}
\hline Assay & No. Cycles & Thermal Conditions \\
\hline \multirow{2}{*}{ IS6110/senX3-regX3 } & 1 & $95^{\circ} \mathrm{C}$ for $2 \mathrm{~min}$ \\
\hline & 45 & $\begin{array}{l}95^{\circ} \mathrm{C} \text { for } 5 \mathrm{~s} \\
60^{\circ} \mathrm{C} \text { for } 15 \mathrm{~s}\end{array}$ \\
\hline \multirow{3}{*}{$r p o B$} & 1 & $94^{\circ} \mathrm{C}$ for $2 \mathrm{~min}$ \\
\hline & 35 & $\begin{array}{l}94^{\circ} \mathrm{C} \text { for } 30 \mathrm{~s} \\
58^{\circ} \mathrm{C} \text { for } 30 \mathrm{~s} \\
72^{\circ} \mathrm{C} \text { for } 40 \mathrm{~s}\end{array}$ \\
\hline & 1 & $72^{\circ} \mathrm{C}$ for $5 \mathrm{~min}$ \\
\hline \multirow{3}{*}{ katG } & 1 & $94^{\circ} \mathrm{C}$ for $2 \mathrm{~min}$ \\
\hline & 40 & $\begin{array}{l}94{ }^{\circ} \mathrm{C} \text { for } 30 \mathrm{~s} \\
60^{\circ} \mathrm{C} \text { for } 30 \mathrm{~s} \\
72{ }^{\circ} \mathrm{C} \text { for } 60 \mathrm{~s}\end{array}$ \\
\hline & 1 & $72{ }^{\circ} \mathrm{C}$ for $5 \mathrm{~min}$ \\
\hline
\end{tabular}

C: Celsius; No.: number.

\section{5. rpoB and katG Mutation Analysis}

Targeted PCR was used to identify mutations in the rpoB and $k a t G$ genes in DNA extracted from the TB clinical samples. Each PCR reaction $(25 \mu \mathrm{L})$ contained 1X GoTaq G2 Green Master Mix (Promega, Madison, WI, USA), 0.5 ( $r p o B)$ or 0.8 (katG) $\mu \mathrm{M}$ each of forward and reverse primer, and $2 \mu \mathrm{L}$ of DNA template. The positive control used MTB H37Rv (GenBank: AL123456.3). The rpoB and $k a t G$ primer sets have been described elsewhere [8], with the published conditions optimised in-house for each protocol, as described in Table 1. The PCR assays were undertaken on BIOER GeneTouch and Kyratec SuperCycler Trinity PCR machines. Amplicons showing single clear bands after agarose gel electrophoresis were sequenced in both directions (Macrogen, Korea). Sequence chromatograms were analysed using Geneious R10 (Biomatters Limited, Auckland, New Zealand), with the consensus sequences of each sample compared to the MTB H37Rv reference sequence (GenBank: AL123456.3). The numbering system used in the results is according to that described previously for MTB H37Rv [32].

\subsection{Analysis of Duplicate and Repeat Samples}

Duplicate samples were excluded from the analyses for four patients. Three patients had both new (initial TB investigation) and follow-up (post-treatment commencement) samples collected and included in the analysis. Follow-up samples were collected at different time-points, ranging from two to four months following treatment commencement.

\subsection{Ethics Approval}

The study was undertaken in collaboration with BDH, and received approval locally from the Middle Fly District Health Service, and the Evangelical Church of PNG Health Service. Human research ethics approval was received from the James Cook University Human Research Ethics Committee (Ethics Approval Number H6432) and the PNG Medical Research Advisory Committee (MRAC No. 17.02).

\section{Results}

\subsection{Demographic Information and Detection of MTB Infection}

Overall, 240 sputum samples were collected, with 236 samples from 233 patients analysed based on the exclusion criteria described previously (see Methods). Patient distributions by age and sex are 
shown in Table 2. Sample status at time of collection, and smear microscopy results for new samples only, are shown in Table 3.

Table 2. Demographics of presumptive tuberculosis (TB) patients in the Balimo region of Papua New Guinea (PNG), from samples collected as part of routine passive case detection activities at Balimo District Hospital (BDH). Out of 240 samples initially collected, a total of 236 samples originating from 233 patients were analysed, as three patients had both new and follow-up samples collected, and four samples were duplicates.

\begin{tabular}{ccc}
\hline Category & - & $\boldsymbol{n} \mathbf{( \% )}$ \\
\hline \multirow{3}{*}{ Sex } & Female & $123(53)$ \\
& Male & $109(47)$ \\
& Unknown & $1(0.4)$ \\
& Total & $233(100)$ \\
\hline \multirow{2}{*}{ Age } & Child (0-17 years) & $16(7)$ \\
& Adult (18+ years) & $216(93)$ \\
& Unknown & $1(0.4)$ \\
& Total &
\end{tabular}

Table 3. Distribution of incoming sample status of all presumptive TB patients, and smear microscopy results for new samples only.

\begin{tabular}{ccc}
\hline Category & - & $\boldsymbol{n}(\mathbf{\%})$ \\
\hline \multirow{3}{*}{ Sample status } & New & $211(89)$ \\
& Follow-up & $21(9)$ \\
& Unknown & $4(2)$ \\
& Total & $236(100)$ \\
\hline \multirow{3}{*}{ Smear microscopy result } & Positive & $32(15)$ \\
& Negative & $176(83)$ \\
& Unknown & $3(1)$ \\
& Total & $211(100)$ \\
\hline
\end{tabular}

$n$ : number.

Based on the classification criteria for molecular detection of MTB (see Methods), a total of $62 / 236$ (26\%, 95\% CI 21-32) samples were classified as MTB, and 24/236 (10\%, 95\% CI 7-15) were classified as MTBC/NTM. The remainder (150/236, 64\%, 95\% CI 57-69) were classified as negative for MTB. Of the 24 samples classified as MTBC/NTM, 22 had Cq values greater than 30 cycles (see Supplementary Material).

\subsection{Mutations Identified in MTB DNA}

Of the 240 sputum samples that were collected, 102 were assessed for resistance using the rpoB and katG primer sets. This included 87 samples classified as MTB $(n=62)$ or MTBC/NTM $(n=25)$, as well as 15 samples reactive for early runs of the IS6110 assay or a rpoB-based assay being tested externally to this study, but ultimately classified as negative. One MTBC/NTM sample was excluded from the results due to being a duplicate (see Methods).

Amplicons were obtained from 53 of the 86 samples classified as MTB or MTBC/NTM. Overall, sequence data was obtained from one MTBC/NTM sample, while all other sequences were obtained from samples classified as MTB.

$r p o B$ sequencing was successful for 50 samples (Table 4). One sample classified as MTB based on qPCR did not match the H37Rv reference strain, and thus may not have been MTB. RIF resistance-associated mutations were identified in five samples, as detailed in Table 4 . These five samples were all classified as new (i.e., they were collected from people undergoing initial investigations for TB). 
Overall, $10 \%$ (5/50, 95\% CI 4-21) of samples with rpoB sequencing were considered to be RIF-resistant, based on identification of a $r p o B$ mutation that is known to confer drug resistance.

Table 4. Summary of sequencing results for the $r p o B$ and $k a t G$ amplicons, including nucleotide and codon mutations.

\begin{tabular}{|c|c|c|c|}
\hline rpoB Result & katG Result & Combined & $n$ \\
\hline WT & WT & WT & 34 \\
\hline WT & $\mathrm{N} / \mathrm{A}$ & rpoB WT & 5 \\
\hline $\mathrm{S}_{450 \mathrm{~L}^{1}}(\mathrm{C} 1349 \mathrm{~T})$ & WT & $\begin{array}{l}\text { RIF-DR } \\
\text { katG WT }\end{array}$ & 4 \\
\hline $\begin{array}{c}\mathrm{S}^{4} 50 \mathrm{~L}^{1} \text { (C1349T) } \\
\mathrm{I} 480 \mathrm{~V}(\mathrm{~A} 1438 \mathrm{G})\end{array}$ & WT & $\begin{array}{l}\text { RIF-DR } \\
\text { katG WT }\end{array}$ & 1 \\
\hline WT or F548L (C1644A) & WT & $\begin{array}{c}\text { rpoB discordant } \\
\text { katG WT }\end{array}$ & 1 \\
\hline $\mathrm{N} / \mathrm{A}$ & WT & katG WT & 1 \\
\hline $\mathrm{N} / \mathrm{A}$ & $\mathrm{P}^{219 L}{ }^{2}$ (C656T) & kat $G$ mutant & 1 \\
\hline $\mathrm{N} / \mathrm{A}$ & $\begin{array}{l}\text { A361V }^{2}(\mathrm{C} 1082 \mathrm{~T}) \\
\text { P365S }^{2}(\mathrm{C} 1093 \mathrm{~T}) \\
\text { S383L }^{2} \text { (C1148T) } \\
\text { R396C }^{2} \text { (C1186T) }\end{array}$ & katG mutant & 1 \\
\hline WT & WT or E261K ${ }^{2}(\mathrm{G} 781 \mathrm{~A})$ & $\begin{array}{c}\text { rpoB WT } \\
\text { katG discordant }\end{array}$ & 1 \\
\hline WT & WT or G279R ${ }^{2}$ (G835C) & $\begin{array}{c}r p o B \mathrm{WT} \\
\text { katG discordant }\end{array}$ & 3 \\
\hline Not matched to ref & $\mathrm{N} / \mathrm{A}$ & Not matched to ref & 1 \\
\hline Total & & & 53 \\
\hline
\end{tabular}

$n$ : number; N/A: not available (amplification or sequencing failed); ref: H37Rv reference genome; RIF-DR: rifampicin drug resistance; WT: wild-type (no mutations identified). ${ }^{1}$ Codon mutation located within the RRDR of the rpoB gene, numbered according to the system based on MTB H37Rv [32]; ${ }^{2}$ kat $G$ mutations with unknown association with drug resistance

$k a t G$ sequencing was successful for 47 samples, with mutations identified in two samples as described in Table 4. We were unable to confirm mutations in five samples because of discordant sequencing results in the forward and reverse strands. These included rpoB WT/F548L in one sample, katG WT/E261K in one sample, and katG WT/G279R in three samples (Table 4). These discordant results were not investigated further due to the high possibility of sequencing error, and as they have not previously been reported or associated with drug resistance their clinical significance is unknown.

\section{Discussion}

This study was undertaken on sputum samples collected in the rural Balimo region of PNG from presumptive TB patients. Molecular diagnostic techniques identified MTB in $26 \%$ to $36 \%$ (when including MTBC/NTM) of the samples. In our setting, classification as MTBC/NTM rather than MTB may have been due to a reduced ability to amplify the single copy senX3-regX3 gene, as a result of low MTB DNA concentration. As such, classification of MTBC/NTM is not considered to exclude MTB, but is simply a lack of confirmation. DR-TB was identified in samples collected at BDH, with RIF resistance-associated mutations identified in 10\% (5/50, 95\% CI 4-21) of the MTB or MTBC/NTM samples where $r p o B$ sequencing was obtained.

The rрoB S450L codon mutation, identified in five samples in this study, is the most frequently identified RIF resistance-associated mutation in the $r p o B$ gene $[33,34]$. This mutation has been described previously in three studies from PNG, including in Western Province $[5,8,13]$. The rpoB I480V codon 
mutation, identified in one sample in this study, is much less common, and was first described in a study from Mexico, where it appeared alongside S450L as in our sample [35]. Interestingly, the same double amino acid change has recently been identified in a single clinical sample collected at Daru Hospital in Western Province, PNG [13]. However, the geographic origin of this patient was not stated.

There is less certainty regarding the INH drug resistance association of the mutations identified in the $k a t G$ gene. In this study S315T, the most common INH resistance-associated kat $G$ mutation, was not identified, despite being seen in other studies from PNG, including in Western Province $[5,8,13]$. However, $k a t G$ mutations were identified in a number of sequences, and these should be investigated further to confirm the possible presence of novel mutations, as well as for phenotypic DST. In addition, the $i n h A$ and $\operatorname{ahpC}$ genes, as well as other genes that have been associated with INH resistance, were not investigated. As a result, neither INH mono-resistance nor MDR-TB could be determined. Despite this finding, genotypic INH resistance should continue to be monitored, as several hundred different kat $G$ mutations have been documented in INH-resistant TB samples [19,36,37], with descriptions of new mutations likely to occur in the future. Additionally, inh $A$ mutations have been identified in INH-resistant MTB strains elsewhere in PNG, including in Western Province $[5,8,13]$.

For this study, repeat sequencing would be necessary to confirm mutations that have not previously been associated with drug resistance, and culture and DST would be required to confirm the phenotypic drug resistance status of $r p o B$ and $k a t G$ mutations identified, especially given some mutations may be seen in both drug-susceptible and drug-resistant isolates $[19,36,38,39]$.

We identified RIF resistance-associated mutations in 10\% (95\% CI 4-21) of samples where rpoB sequencing was successful, indicating that DR-TB is already an established concern in the Middle Fly District. As described earlier, a high proportion of DR-TB has been described at Daru Hospital in the South Fly District of Western Province [4]. However, as Daru Hospital is the site for Xpert MTB/RIF testing of samples from across Western Province [27], clinical samples tested there will have originated from local residents as well as patients from elsewhere in the province, including Balimo. As a result, the proportion of DR-TB identified in Daru would be expected to be higher than the national average. The earlier study describing DR-TB in Daru, in combination with the results of our study undertaken in Balimo, highlight the geographic reach of DR-TB across much of Western Province.

This was a small study, undertaken on samples collected on a passive case detection basis at $\mathrm{BDH}$. The study was a laboratory-based analysis of samples collected as part of passive case detection activities at $\mathrm{BDH}$, and the $\mathrm{TB}$ treatment history of patients was not recorded in the laboratory register. Furthermore, sequencing results were not obtained for 33 of the samples classified as MTB or MTBC/NTM. A larger study would be necessary to provide greater understanding of the epidemiology of DR-TB in the Balimo region. Further investigation would be particularly useful in understanding the treatment history and geographic distribution of DR-TB patients, and the genetic diversity of DR-TB strains.

\section{Conclusions}

This study has described the presence of RR-TB in the Balimo region, based on the identification of resistance-associated mutations in the $r p o B$ gene. These findings extend our earlier research in Balimo, which has described a heavy burden of TB in the region, and highlighted the potential underdiagnosis of smear-negative pulmonary TB at BDH [24,26]. Identification of RR-TB in the Balimo region emphasises the need for further investigation of the DR-TB burden in the Middle Fly District of Western Province. Analysis of the TB treatment history of DR-TB patients would provide insight into the contribution of the various pathways to DR-TB in this region, that is, development versus transmission. Implementation in Balimo of a method such as the WHO-recommended Xpert MTB/RIF, which is capable of TB diagnosis and detection of RIF resistance, should be considered. Currently in Balimo, clinical samples from presumptive DR-TB patients must be sent to the provincial capital of Daru for Xpert MTB/RIF testing [27]. If the sample is positive, the patient must then travel to Daru to be commenced on DR-TB treatment, with completion under the supervision of an 
appropriately trained health worker [27]. Potential patient and provider challenges associated with this approach include delays in initiation of adequate treatment, active transmission of DR-TB to others, loss-to-follow-up while waiting for diagnostic results, and access challenges due to the long travel time to reach Daru. The presence of RIF resistance in this region distant from Daru emphasises the importance of understanding the heterogeneity of DR-TB across Western Province. Improving resources and facilities at $\mathrm{BDH}$ for local management of $\mathrm{TB}$ and DR-TB patients may reduce the strain placed on Daru Hospital, and play a role in the management of DR-TB patients in Western Province.

Supplementary Materials: The following are available online at http:/ / www.mdpi.com/2414-6366/4/1/33/s1, Table S1: Details of qPCR and sequencing results.

Author Contributions: Conceptualization, T.D.-E., V.G., G.B., E.M., D.P. (David Plummer) and J.W.; Data curation, T.D.-E. and V.G.; Formal analysis, T.D.-E., V.G., G.B. and D.P. (Daniel Pelowa); Funding acquisition, E.M., C.R. and J.W.; Investigation, T.D.-E., V.G., D.P. (Daniel Pelowa), R.D., B.G. and J.W.; Methodology, T.D.-E., V.G., G.B. and J.W.; Project administration, T.D.-E., V.G. and J.W.; Resources, G.B., D.P. (Daniel Pelowa) and J.W.; Supervision, G.B., William Pomat, E.M., D.P. (David Plummer), C.R. and J.W.; Validation, T.D.-E., V.G. and M.P.; Visualization, T.D.-E. and V.G.; Writing-original draft, T.D.-E. and V.G.; Writing-review \& editing, T.D.-E., V.G., G.B., D.P. (Daniel Pelowa), R.D., B.G., M.P., W.P., E.M., D.P. (David Plummer), C.R. and J.W.

Funding: This research was funded by two unrestricted grants from the Queensland Government Department of Science, Information Technology and Innovation (DSITI) through the Australian Institute of Tropical Health and Medicine (AITHM). The grant recipients were (1) Emma McBryde and Jeffrey Warner; and (2) Catherine Rush and Jeffrey Warner.

Acknowledgments: We thank Suli Gayani and Kimsy Waiwa for their support of this project. Research undertaken by Tanya Diefenbach-Elstob was supported by an Australian Government Research Training Program (RTP) Scholarship.

Conflicts of Interest: The authors declare no conflict of interest. The funders had no role in the design of the study; in the collection, analyses, or interpretation of data; in the writing of the manuscript, or in the decision to publish the results.

\section{References}

1. World Health Organization. Global Tuberculosis Report 2018; World Health Organization: Geneva, Switzerland, 2018. Available online: http:/ / apps.who.int/iris/bitstream/handle/10665/274453/9789241565646-eng.pdf? ua=1 (accessed on 9 February 2019).

2. Aia, P.; Wangchuk, L.; Morishita, F.; Kisomb, J.; Yasi, R.; Kal, M.; Islam, T. Epidemiology of tuberculosis in Papua New Guinea: Analysis of case notification data and treatment-outcome data, 2008-2016. Western Pac. Surveill. Response J. 2018, 9. [CrossRef] [PubMed]

3. McBryde, E. Evaluation of Risks of Tuberculosis in Western Province Papua New Guinea; Department of Foreign Affairs and Trade: Barton, Australia, 2012. Available online: https:/ / www.burnet.edu.au/system/ publication/file/3606/2012_Evaluation_of_Risks_of_Tuberculosis_in_Western_Province_PNG.pdf (accessed on 9 February 2019).

4. Aia, P.; Kal, M.; Lavu, E.; John, L.N.; Johnson, K.; Coulter, C.; Ershova, J.; Tosas, O.; Zignol, M.; Ahmadova, S.; et al. The burden of drug-resistant tuberculosis in Papua New Guinea: Results of a large population-based survey. PLoS ONE 2016, 11, e0149806. [CrossRef] [PubMed]

5. Ley, S.D.; Harino, P.; Vanuga, K.; Kamus, R.; Carter, R.; Coulter, C.; Pandey, S.; Feldmann, J.; Ballif, M.; Siba, P.M.; et al. Diversity of Mycobacterium tuberculosis and drug resistance in different provinces of Papua New Guinea. BMC Microbiol. 2014, 14, 307. [CrossRef] [PubMed]

6. Cross, G.B.; Coles, K.; Nikpour, M.; Moore, O.A.; Denholm, J.; McBryde, E.S.; Eisen, D.P.; Warigi, B.; Carter, R.; Pandey, S.; et al. TB incidence and characteristics in the remote gulf province of Papua New Guinea: A prospective study. BMC Infect. Dis. 2014, 14, 93. [CrossRef] [PubMed]

7. Ballif, M.; Harino, P.; Ley, S.; Carter, R.; Coulter, C.; Niemann, S.; Borrell, S.; Fenner, L.; Siba, P.; Phuanukoonnon, S.; et al. Genetic diversity of Mycobacterium tuberculosis in Madang, Papua New Guinea. Int. J. Tuberc. Lung Dis. 2012, 16, 1100-1107. [CrossRef] [PubMed]

8. Ballif, M.; Harino, P.; Ley, S.; Coscolla, M.; Niemann, S.; Carter, R.; Coulter, C.; Borrell, S.; Siba, P.; Phuanukoonnon, S.; et al. Drug resistance-conferring mutations in Mycobacterium tuberculosis from Madang, Papua New Guinea. BMC Microbiol. 2012, 12, 191. [CrossRef] [PubMed] 
9. Kirby, T. Extensively drug-resistant tuberculosis hovers threateningly at Australia's door. Med. J. Aust. 2013, 198, 355. [CrossRef] [PubMed]

10. Furin, J.; Cox, H. Outbreak of multidrug-resistant tuberculosis on Daru Island. Lancet Respir. Med. 2016, 4, 347-349. [CrossRef]

11. Kase, P.; Dakulala, P.; Bieb, S. Outbreak of multidrug-resistant tuberculosis on Daru Island: An update. Lancet Respir. Med. 2016, 4, e40. [CrossRef]

12. TB Drug Resistance Types. Available online: http://www.who.int/tb/areas-of-work/drug-resistant-tb/ types/en/ (accessed on 13 August 2018).

13. Bainomugisa, A.; Lavu, E.; Hiashiri, S.; Majumdar, S.; Honjepari, A.; Moke, R.; Dakulala, P.; Hill-Cawthorne, G.A.; Pandey, S.; Marais, B.J.; et al. Multi-clonal evolution of multi-drug-resistant/extensively drug-resistant Mycobacterium tuberculosis in a high-prevalence setting of Papua New Guinea for over three decades. Microb. Genom. 2018, 4. [CrossRef] [PubMed]

14. Gilpin, C.M.; Simpson, G.; Vincent, S.; O’Brien, T.P.; Knight, T.A.; Globan, M.; Coulter, C.; Konstantinos, A. Evidence of primary transmission of multidrug-resistant tuberculosis in the Western Province of Papua New Guinea. Med. J. Aust. 2008, 188, 148-152. [PubMed]

15. Simpson, G.; Coulter, C.; Weston, J.; Knight, T.; Carter, R.; Vincent, S.; Robertus, L.; Konstantinos, A. Resistance patterns of multidrug-resistant tuberculosis in Western Province, Papua New Guinea. Int. J. Tuberc. Lung Dis. 2011, 15, 551-552. [CrossRef] [PubMed]

16. World Health Organization. Technical Report on Critical Concentrations for Drug Susceptibility Testing of Medicines Used in the Treatment of Drug-Resistant Tuberculosis; World Health Organization: Geneva, Switzerland, 2018. Available online: http://www.who.int/tb / publications/2018/WHO_technical_report_ concentrations_TB_drug_susceptibility/en/ (accessed on 9 February 2019).

17. Ramaswamy, S.; Musser, J.M. Molecular genetic basis of antimicrobial agent resistance in Mycobacterium tuberulosis: 1998 update. Tuber. Lung Dis. 1998, 79, 3-29. [CrossRef] [PubMed]

18. Musser, J.M. Antimicrobial agent resistance in mycobacteria: Molecular genetic insights. Clin. Microbiol. Rev. 1995, 8, 496-514. [CrossRef] [PubMed]

19. Vilchèze, C.; Jacobs, W.R., Jr. Resistance to isoniazid and ethionamide in Mycobacterium tuberculosis: Genes, mutations, and causalities. Microbiol. Spectr. 2014, 2. [CrossRef] [PubMed]

20. Traore, H.; Fissette, K.; Bastian, I.; Devleeschouwer, M.; Portaels, F. Detection of rifampicin resistance in Mycobacterium tuberculosis isolates from diverse countries by a commercial line probe assay as an initial indicator of multidrug resistance. Int. J. Tuberc. Lung Dis. 2000, 4, 481-484. [PubMed]

21. Adikaram, C.P.; Perera, J.; Wijesundera, S.S. Geographical profile of rpoB gene mutations in rifampicin resistant Mycobacterium tuberculosis isolates in Sri Lanka. Microb. Drug Resist. 2012, 18, 525-530. [CrossRef] [PubMed]

22. Badie, F.; Arshadi, M.; Mohsenpoor, M.; Gharibvand, S.S. Drug resistance pattern of Mycobacterium tuberculosis isolates from patients referred to TB reference laboratory in Ahvaz. Osong Public Health Res. Perspect 2016, 7, 32-35. [CrossRef] [PubMed]

23. Manson, A.L.; Cohen, K.A.; Abeel, T.; Desjardins, C.A.; Armstrong, D.T.; Barry, I.I.I.C.E.; Brand, J.; TBResist Global Genome Consortium; Chapman, S.B.; Cho, S.-N.; et al. Genomic analysis of globally diverse Mycobacterium tuberculosis strains provides insights into the emergence and spread of multidrug resistance. Nat. Genet. 2017, 49, 395-402. [CrossRef] [PubMed]

24. Diefenbach-Elstob, T.; Graves, P.; Dowi, R.; Gula, B.; Plummer, D.; McBryde, E.; Pelowa, D.; Siba, P.; Pomat, W.; Warner, J. The epidemiology of tuberculosis in the rural Balimo region of Papua New Guinea. Trop. Med. Int. Health 2018, 23, 1022-1032. [CrossRef] [PubMed]

25. National Statistical Office. 2011 National Population \& Housing Census: Ward Population Profile-Southern Region; National Statistical Office: Port Moresby, Papua New Guinea, 2014. Available online: http:/ /www. nso.gov.pg/index.php/document-library?view=download\&fileId=64 (accessed on 9 February 2019).

26. Guernier, V.; Diefenbach-Elstob, T.; Pelowa, D.; Pollard, S.; Burgess, G.; McBryde, E.S.; Warner, J. Molecular diagnosis of suspected tuberculosis from archived smear slides from the Balimo region, Papua New Guinea. Int. J. Infect. Dis. 2018, 67, 75-81. [CrossRef] [PubMed]

27. Department of Health. Papua New Guinea: National Tuberculosis Management Protocol; Department of Health: Port Moresby, Papua New Guinea, 2011. Available online: http:/ /www.adi.org.au/wp-content/uploads / 2016/11/National-Tuberculosis-Management-Protocol-PNG-2011.pdf (accessed on 9 February 2019). 
28. Petroff, S.A. A new and rapid method for the isolation and cultivation of tubercle bacilli directly from the sputum and feces. J. Exp. Med. 1915, 21, 38. [CrossRef] [PubMed]

29. Kent, P.T.; Kubica, G.P. Public Health Mycobacteriology: A Guide for the Level III Laboratory. Available online: https:/ /ntrl.ntis.gov/NTRL/dashboard/searchResults/titleDetail/PB86216546.xhtml (accessed on 9 February 2019).

30. Broccolo, F.; Scarpellini, P.; Locatelli, G.; Zingale, A.; Brambilla, A.M.; Cichero, P.; Sechi, L.A.; Lazzarin, A.; Lusso, P.; Malnati, M.S. Rapid diagnosis of mycobacterial infections and quantitation of Mycobacterium tuberculosis load by two real-time calibrated PCR assays. J. Clin. Microbiol. 2003, 41, 4565-4572. [CrossRef] [PubMed]

31. Ley, S.; Carter, R.; Millan, K.; Phuanukoonnon, S.; Pandey, S.; Coulter, C.; Siba, P.; Beck, H.-P. Non-tuberculous mycobacteria: Baseline data from three sites in Papua New Guinea, 2010-2012. Western Pac. Surveill. Response J. 2015, 6, 24-29. [CrossRef] [PubMed]

32. Andre, E.; Goeminne, L.; Cabibbe, A.; Beckert, P.; Kabamba Mukadi, B.; Mathys, V.; Gagneux, S.; Niemann, S.; Van Ingen, J.; Cambau, E. Consensus numbering system for the rifampicin resistance-associated rpoB gene mutations in pathogenic mycobacteria. Clin. Microbiol. Infect. 2017, 23, 167-172. [CrossRef] [PubMed]

33. Heep, M.; Brandstätter, B.; Rieger, U.; Lehn, N.; Richter, E.; Rüsch-Gerdes, S.; Niemann, S. Frequency of $r p o B$ mutations inside and outside the cluster I region in rifampin-resistant clinical Mycobacterium tuberculosis isolates. J. Clin. Microbiol. 2001, 39, 107-110. [CrossRef] [PubMed]

34. Brandis, G.; Hughes, D. Genetic characterization of compensatory evolution in strains carrying rpoB Ser531Leu, the rifampicin resistance mutation most frequently found in clinical isolates. J. Antimicrob. Chemother. 2013, 68, 2493-2497. [CrossRef] [PubMed]

35. Ramaswamy, S.V.; Dou, S.-J.; Rendon, A.; Yang, Z.; Cave, M.D.; Graviss, E.A. Genotypic analysis of multidrug-resistant Mycobacterium tuberculosis isolates from Monterrey, Mexico. J. Med. Microbiol. 2004, 53, 107-113. [CrossRef] [PubMed]

36. Seifert, M.; Catanzaro, D.; Catanzaro, A.; Rodwell, T.C. Genetic mutations associated with isoniazid resistance in Mycobacterium tuberculosis: A systematic review. PLoS ONE 2015, 10, e0119628. [CrossRef] [PubMed]

37. Sandgren, A.; Strong, M.; Muthukrishnan, P.; Weiner, B.K.; Church, G.M.; Murray, M.B. Tuberculosis drug resistance mutation database. PLoS Med. 2009, 6, e1000002. [CrossRef] [PubMed]

38. Domínguez, J.; Boettger, E.C.; Cirillo, D.; Cobelens, F.; Eisenach, K.D.; Gagneux, S.; Hillemann, D.; Horsburgh, R.; Molina-Moya, B.; Niemann, S.; et al. Clinical implications of molecular drug resistance testing for Mycobacterium tuberculosis: A TBNET/RESIST-TB consensus statement. Int. J. Tuberc. Lung Dis. 2016, 20, 24-42. [CrossRef] [PubMed]

39. Jamieson, F.B.; Guthrie, J.L.; Neemuchwala, A.; Lastovetska, O.; Melano, R.G.; Mehaffy, C. Profiling of $r p o B$ mutations and MICs for rifampin and rifabutin in Mycobacterium tuberculosis. J. Clin. Microbiol. 2014, 52, 2157-2162. [CrossRef] [PubMed]

(C) 2019 by the authors. Licensee MDPI, Basel, Switzerland. This article is an open access article distributed under the terms and conditions of the Creative Commons Attribution (CC BY) license (http://creativecommons.org/licenses/by/4.0/). 